\title{
Barriers to leisure-time physical activity in adults living in a low socioeconomic area of the Brazilian Southeast
}

\author{
Barreiras à prática de atividade física no tempo de lazer em adultos residentes em área \\ de baixo nível socioeconômico do sudeste brasileiro
}

\section{AUTHOR'S \\ Michele Santos da Cruz ${ }^{1}$ (D) \\ Leandro Martin Totaro Garcia ${ }^{1}$ (D) \\ Douglas Roque Andrade ${ }^{2}$ (D) \\ Alex Antonio Florindo ${ }^{1,2}$ (iD) \\ 1 Faculdade de Saúde Pública da Universidade de São Paulo, Departamento de Nutrição, São Paulo, São Paulo, Brasil. \\ 2 Escola de Artes, Ciências e Humanidades da Universidade de São Paulo, Grupo de Estudos e Pesquisas Epidemiológicas em Atividade Física e Saúde (GEPAF - USP). São Paulo, São Paulo, Brasil.}

\section{CORRESPONDING}

Michele Santos da Cruz

chele1213@gmail.com

Rua São Carlos do Pinhal, 79, apto 114,

Bela vista, São Paulo, São Paulo, Brasil.

CEP: 01333-900.

DOI

10.12820/rbafs.23e0041

\begin{abstract}
The aim of this study was to describe the main perceived barriers to engagement in leisure-time physical activity and associated factors among adults from the Ermelino Matarazzo district, Sao Paulo, Southeast, Brazil. Data were obtained from a population-based household survey conducted in 2007 involving 889 subjects ( $\geq 18$ years). The long version of the International Physical Activity Questionnaire was used to identify physically inactive individuals. Open question about barriers was applied only for people inactive in leisure and content analysis was conducted to categorize the barriers. Descriptive analysis was performed using frequencies. Bivariate associations between the five most frequently reported barriers and sociodemographic variables, reported diagnoses of chronic diseases, nutritional status, working timing, travel time (to work and school), and television watching were determined using the chi-square test. Results showed that the five most prevalent barriers were lack of time (39.7\%), lack of desire or motivation (18.4\%), dislike exercising (6.3\%), have an injury or disease (5.6\%), and lack of money (3.6\%). The vulnerable groups to lack of time were people married, young and middle aged, and with longer labor journey. Health problems were related by people with hypertension, diabetes, heart diseases, elderly, with low education and who did not have labor activities. People who were not working, with low education and income, and with hypertension related more dislike of exercising. Lack of desire or motivation was most cited among people who watched television. These results are important to support community programs promoting leisure-time physical activity in areas with low socioeconomic status.
\end{abstract}

Keywords: Engagement; Physical activity; Leisure time; Barriers.

RESUMO

O objetivo deste estudo foi descrever as principais barreiras à prática de atividade física no tempo de lazer e fatores associados em adultos do distrito de Ermelino Matarazzo, município de São Paulo, Sudeste, Brasil. Utilizou-se dados de inquérito domiciliar de base populacional de 2007, com 889 sujeitos com 18 anos ou mais de idade. Aplicou-se Questionário Internacional de Atividades Físicas versão longa, questão aberta sobre barreiras foi aplicada somente aos fisicamente inativos no lazer e análise de conteúdo conduzida para categorizá-las. Foram realizadas análises de associação bivariadas entre as cinco barreiras mais relatadas com variáveis sociodemográficas, autorrelato de doenças crônicas, estado nutricional, tempo de trabalho, tempo gasto com deslocamentos e hábito de assistir utilizando-se o teste qui-quadrado. Os resultados mostraram que as cinco barreiras mais prevalentes foram falta de tempo (39,7\%), falta de vontade ou motivaçôes $(18,4 \%)$, não gostar de fazer exercícios (6,3\%), problemas de saúde (5,6\%) e falta de dinheiro (3,6\%). Os grupos vulneráveis à falta de tempo eram pessoas casadas, jovens e de meia-idade e com jornada de trabalho mais longa. Os problemas de saúde foram relatados por pessoas com hipertensão, diabetes, cardiopatias, idosos, pessoas com baixa escolaridade e que não trabalhavam. Pessoas com baixa escolaridade e renda, que não trabalham, e com hipertensão reportaram mais não gostar de se exercitar. A falta de vontade ou motivação foi mais citada entre pessoas que assistiam televisão. Esses resultados são importantes para embasar programas comunitários de promoção da atividade física no tempo de lazer em regiôes de baixo nivel socioeconômico.

Palavras-chave: Adesão; Atividade física; Tempo de lazer; Barreiras.

\section{Introduction}

There are a vast number of evidences in the literature on the benefits of regular physical activity for health ${ }^{1-4}$.
However, despite the evidence, the number of individuals that find it difficult to commence or remain regularly engaged in physical activity programs is high, 
particularly in leisure-time physical activity.

Florindo et al..$^{5}$ found a $60 \%$ prevalence of physical inactity in leisure time in ten major Brazilian cities and trend analisys showed few changes in this cenario ${ }^{6}$. Similarly, Florindo et al. ${ }^{7}$ and Salvador et al. ${ }^{8}$ revealed that only $15 \%$ of adults and elderly were physically active during leisure time in Ermelino Matarazzo district, region with a low socioeconomic level in Sao Paulo city, Brazil.

Inequities can influence physical activity in low-income and middle income-countries. According to Sallis et al. ${ }^{9}$, a physically active lifestyle in adults and elderly people living in low-income and middle-income countries are associated with demographic and biological factors (young people, male and people with better education and income are more active in leisure time), psychological, cognitive, and emotional factors (mainly expected benefits, perceived health and fitness, and self-efficacy), social and cultural factors (mainly social support from friends and peers), and built environment factors (mainly access to destinations, enjoy able landscapes and aesthetics, urban location of residence, access to open spaces, and street connectivity). Barriers are defined as obstacles perceived by the individual that can reduce their engagement in healthy behaviors ${ }^{10}$, can include many of these factors pointed by Sallis et al. ${ }^{9}$.

Lack of time, lack of money, low social support and motivation, and health problems are barriers associated with physical inactivity in leisure time ${ }^{10,11}$. Study conducted by Reichert et al. ${ }^{12}$ identified a dose-response relationship between the number of barriers cited by the individuals and the likelihood of being physically inactive during leisure time. In addition, the authors found as main barriers lack of time, dislike exercising, feel too tired, lack of company, lack of money, have an injury or disease, feel too old, and fear of injury.

Recent systematic review about Brazilian studies that examined barriers to physical activity identified 25 studies, totaling 62,678 reports of barriers, being eight in adults and six in elderly. In addition, the intrapersonal were the barriers most reported by adults and elderly people. However, there are few epidemiologic studies about barriers for physical activity in leisure time conducted in low socioeconomic areas and that had randomized sample ${ }^{13}$. For example, systematic review identified seven Brazilian studies with adults, but none was conducted in low socioeconomic area, where the people social, demographic and environmental conditions can be very different ${ }^{13}$.
In order to enable individuals to commence and maintain regular physical activity, it is important to determine and overcome the most common barriers. This knowledge can support health professionals and public managers in reducing these modifiable barriers, particularly in regions with low socioeconomic level in low, middle, and middle-high income countries as Brazil to provide evidences to interventions. Therefore, the aim of the present study were: 1) to describe the main barriers to engaging in leisure-time physical activity among adults from the district Ermelino Matarazzo, a region with a low socioeconomic level in east zone in São Paulo city, Southeast, Brazil; 2) to identify bivariate association of the main barriers with sociodemographic variables, reported diagnoses of chronic diseases, nutritional status, working timing, travel time (to work and school), and television watching.

\section{Methods}

Data were drawn from a cross-sectional population-based household survey conducted in 2007 in Ermelino Matarazzo district, which is located in São Paulo city, east zone, São Paulo, Southeast, Brazil.

In 2007, Ermelino Matarazzo had 112,068 in habitants in an area of $8.95 \mathrm{~km}^{2}$ and demographic density of 12,521 persons $/ \mathrm{km}^{2}$. In 2018, the population increased to $117,821^{14}$. The district has more social and economic inequities than other places in Sao Paulo city. When compared to Moema, district that is located in south of São Paulo city and that has the highest income per capita in Sao Paulo, Ermelino Matarazzo has more unemployment, lower income, life expectancy, and higher infant mortality ${ }^{14,15}$.

The sample consisted of 889 subjects, comprising 384 elderly (aged $\geq 60$ years) and 505 adults (18-59 years). Study inclusion criteria were participants living at the selected address for at least six months. Exclusion criteria were being unable to engage in physical activity for leisure or transport, having cognitive impairments or other disabilities preventing from answering the questionnaire alone, and being pregnant. Further details about sample size and sample selection can be found in the publications of Florindo et al. ${ }^{7}$ and Salvador et al. ${ }^{8}$. In general, the interviers visited with success 1,985 homes and did 890 interviews (response rate $=72.6 \%)^{8}$.

Physical activity was assessed using the leisure module of the long version of the International Physical Activity Questionnaire (IPAQ), previously used 
in studies conducted in Brazil ${ }^{16,17}$. The questionnaire was adapted and some additional questions were incorporated in the leisure module like frequencies and duration of three types of moderate and vigorous physical activies. The questionnaire applied was validated by Garcia et al. ${ }^{18}$ in sample of adults and elderly from Ermelino Matarazzo and exhibited satisfactory validity based on comparison with accelerometer measurements. Significant correlation was confirmed between minutes of moderate-to-vigorous physical activity measured by accelerometer and minutes of transport-related and leisure-time physical activity measured using IPAQ.

Leisure-time physical activity was determined based on activities undertaken in the past week for recreation, sports, exercises or leisure for at least 10 consecutive minutes. Individuals not performing at least 10 minutes of these types of activities in the week leading up to the interview were considered inactive during the leisure time.

The question about barriers to physical activity was answered only by those respondents who reported being physically inactive during leisure time (inclusion criteria). The following open question was posed: "Why do not you engage in leisure-time physical activity, such as walking, moderate or vigorous activities?". Each respondent cited as many barriers as they deemed relevant.

This study also employed the following variables collected during the interview: gender, age (18-39, 40$59, \geq 60$ years), education ( $0-3,4-7, \geq 8$ years), marital status (married, separated, widowed or divorced, single), monthly family income ( $\leq 3$ minimum wages, > 3-5 minimum wage, $>5-7$ minimum wage, $>7$ minimum wage in Brazilian reais), weekly labor hours (not working, 6-40 hours, $\geq 41$ hours), reported diagnoses of arterial hypertension, diabetes or heart diseases (yes or no), obesity (body mass index, BMI $\geq 30.0 \mathrm{~kg} / \mathrm{m}^{2}$ : yes or no), time spent in transportation to work or school/university (zero, < 1 hour, $\geq 1$ hour), and television watching (yes or no).

The first author read all responses and identified the words or phrases describing the barriers reported. This process of treatment of the data was based on content analysis proposed by Bardin ${ }^{19,20}$. There were created categories from the answers and was built similarities groups according to Reichert et al. ${ }^{12}$. Each barrier was identified in the questionnaires and assigned a numeric code. The respectives codes were then keyed into Epidata software, version 3.1, using double-entry and checked using the validate function. All barriers reported were expressed as relative frequencies (\%) and $95 \%$ confidence interval $(95 \% \mathrm{CI})$.

The bivariate association between the five most reported barriers and the sociodemographic variables, self-report of chronic diseases, and obesity were analyzed using the chi-squared test adopting level of significance of $\mathrm{p}$-value $\leq 0.05$.

For data analysis, the sample was weighted according to age group and the sample proportion from the censu stract, estimated from the 2000 Census by Brazilian Institute of Geography and Statistics. The statistical software package Stata was employed for all analyses (version SE 12.1, StataCorp, College Station).

The project was approved by the Research Ethics Committee of the School of Public Health atthe University of São Paulo (number 1488/2006). All participants were given an explanation of the study objectives and signed the free and informed consent form prior to interview.

\section{Results}

The sample comprised predominantly of individuals aged $18-39$ years $(52.1 \%)$, female $(55.2 \%)$, with $\geq 8$ years of education $(60.7 \%)$, married $(56.8 \%)$, with a monthly family income up to 3 minimum wages (45.8\%), and who were working (58.5\%). Prevalence of hypertension was $23.2 \%$ and $15.6 \%$ of people were obese (Table 1).

The prevalence of inactivity in leisure time was $68.5 \%$. Female, people aged 40 years or more, with up to three years of education, married, and with hypertension were more physically inactive (Table 1).

All barriers reported by the subjects were grouped into categories defined according to their similarities as follows: a) lack of time, b) lack of desire or motivation, c) dislike exercising, d) health problems lack of money, e) lack of suitable place, f) lack of partner, g) already moves a lot in the daily routine,h) lack of safety, i) consider themselves too old, $\mathrm{j}$ ) feeling too tired, $\mathrm{k}$ ) places unfavorable, 1) do not know how to ride or do not have a bike, $m$ ) consider the weather unfavorable, $n$ ) fear of injury. Barriers ' $\mathrm{g}$ ' to 'o' were reported by less than $1 \%$ of the respondents and, therefore, were grouped together (Figure 1).

The five most cited barriers were lack of time (39.7\%), lack of desire or motivation (18.4\%), dislike exercising (6.3\%), health problems (5.6\%), and lack of money (3.6\%) - Figure 1 and Table 2. 
Table 1 - Characteristics of sample according to physical inactivity in leisure time. Ermelino Matarazzo, Sao Paulo city, São Paulo, Southeast, Brazil. 2007 ( $\mathrm{n}=889)$.

\begin{tabular}{|c|c|c|c|c|c|}
\hline \multirow[t]{2}{*}{ Variables } & \multicolumn{2}{|c|}{$\begin{array}{l}\text { Total sample } \\
(\mathrm{n}=889)\end{array}$} & \multicolumn{3}{|c|}{ Physically inactive during leisure time } \\
\hline & $\mathrm{n}^{*}$ & $\%^{* *}$ & $\%{ }^{* *}$ & $95 \% \mathrm{CI}$ & $\mathrm{p}$ \\
\hline \multicolumn{6}{|l|}{ Gender } \\
\hline Male & 368 & 44.8 & 60.4 & $51.5-68.7$ & $0.001^{a}$ \\
\hline Female & 521 & 55.2 & 75.0 & $68.7-80.3$ & \\
\hline \multicolumn{6}{|l|}{ Age (years) } \\
\hline $18-39$ & 302 & 52.1 & 59.3 & $50.1-67.9$ & $0.001^{\mathrm{a}}$ \\
\hline $40-59$ & 203 & 35.4 & 81.6 & $73.1-87.7$ & \\
\hline$\geq 60$ & 384 & 12.5 & 69.4 & $62.5-75.5$ & \\
\hline \multicolumn{6}{|l|}{ Education (years of study) } \\
\hline $0-3$ & 242 & 16.2 & 86.4 & $79.4-91.2$ & $0.001^{a}$ \\
\hline $4-7$ & 235 & 23.1 & 77.0 & $69.7-83.0$ & \\
\hline$\geq 8$ & 411 & 60.7 & 60.3 & $51.6-68.5$ & \\
\hline \multicolumn{6}{|l|}{ Marital Status } \\
\hline Married & 457 & 56.8 & 78.7 & $72.1-84.1$ & $0.001^{2}$ \\
\hline Separated, widowed, divorced & 251 & 12.4 & 71.5 & $59.2-81.2$ & \\
\hline Single & 180 & 30.8 & 48.4 & $38.0-58.9$ & \\
\hline \multicolumn{6}{|l|}{ Family Income (minimum wage) } \\
\hline$\leq 3$ & 396 & 45.8 & 74.0 & $64.7-81.6$ & 0.182 \\
\hline$>3-5$ & 160 & 23.7 & 68.7 & $57.0-78.4$ & \\
\hline$>5-7$ & 97 & 14.6 & 64.8 & $50.0-77.3$ & \\
\hline$>7$ & 87 & 15.9 & 58.9 & $43.1-73.1$ & \\
\hline \multicolumn{6}{|l|}{ Weekly working time (hours) } \\
\hline Not working & 479 & 41.5 & 71.8 & $63.4-78.9$ & 0.050 \\
\hline $6-40$ & 125 & 18.7 & 58.1 & $45.9-69.4$ & \\
\hline$\geq 41$ & 279 & 39.8 & 70.3 & $62.4-77.1$ & \\
\hline \multicolumn{6}{|l|}{ Hypertension } \\
\hline Yes & 325 & 23.2 & 81.9 & $75.0-87.3$ & 0.001 \\
\hline No & 563 & 76.8 & 64.3 & $56.5-71.4$ & \\
\hline \multicolumn{6}{|l|}{ Diabetes } \\
\hline Yes & 100 & 5.8 & 74.3 & $59.7-84.9$ & 0.344 \\
\hline No & 785 & 94.2 & 68.0 & $61.2-74.1$ & \\
\hline \multicolumn{6}{|l|}{ Heart diseases } \\
\hline Yes & 78 & 6.7 & 75.6 & $57.2-87.8$ & 0.338 \\
\hline No & 811 & 93.3 & 67.9 & $61.1-74.1$ & \\
\hline \multicolumn{6}{|l|}{ Obesity $\left(\mathrm{BMI} \geq 30 \mathrm{~kg} / \mathrm{m}^{2}\right)$} \\
\hline Yes & 140 & 15.6 & 75.8 & $65.3-83.9$ & 0.094 \\
\hline No & 667 & 84.4 & 66.2 & $58.2-73.4$ & \\
\hline \multicolumn{6}{|l|}{$\begin{array}{l}\text { Time spent in travel } \\
\text { (to work and/or to school) }\end{array}$} \\
\hline 0 & 500 & 42.6 & 73.1 & $65.0-79.8$ & $0.028^{a}$ \\
\hline$<1$ hour & 259 & 36.7 & 61.3 & $52.2-69.7$ & \\
\hline$\geq 1$ hour & 126 & 20.7 & 72.3 & $61.3-81.1$ & \\
\hline \multicolumn{6}{|l|}{ Television watching } \\
\hline Yes & 727 & 79.3 & 69.4 & $62.6-75.4$ & 0.324 \\
\hline No & 162 & 20.7 & 64.9 & $53.7-74.6$ & \\
\hline
\end{tabular}

*Absolute numbers in unweighted sample; ** Prevalence in weighted sample; *** Minimum wage in 2007 was R $\$ 380.00$, equivalent to US\$ $214.69 ; \mathrm{a}=\mathrm{p}<0.005$. 


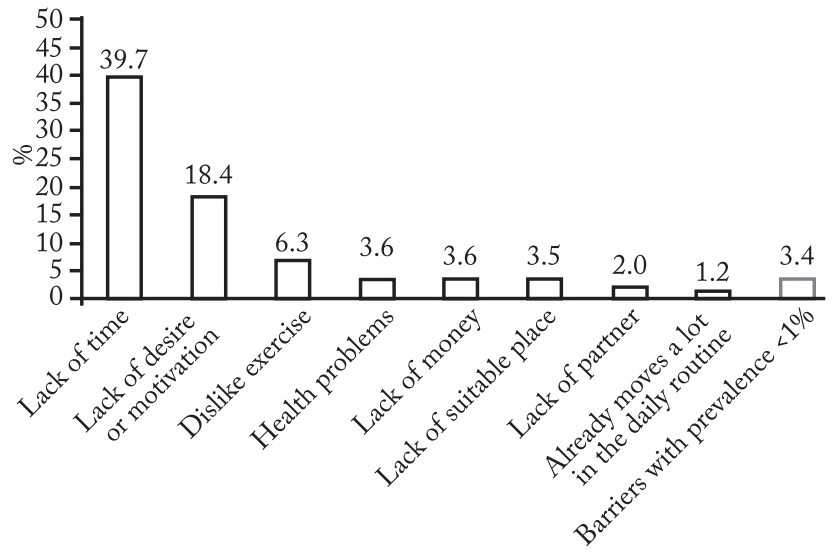

Figure 1 - Barriers to not engaging in leisure-time physical activity with a prevalence higher than $1 \%(n=889)$.

A higher number of adults aged up to 59 years reported lack of time as a barrier (84.7\%), however, more elderly people reported health problems compared to younger and middle aged adults (18.1\%). A higher number of individuals with lower income and education reported dislike exercising than those with greater income and education (9.3\%; 13.5\%; respectively). Individuals with lower education perceived health problems as a barrier more frequently than individuals with greater education (14.7\%). Married and people working over 41 hours per week more often reported lack of time than individuals who were separated, widowed or divorced and those not working (48.9\%; 53.1\%; respectively). Individuals that had hypertension, heart diseases and diabetes cited health problems as major barriers (15.5\%; 18.6\%; 17.1\%, respectively) - Table 2 .

Analysis of the question on travel time (travel to work and school) revealed that individuals who traveled for $\geq 1$ hour reported lack of time as a barrier to engaging in physical activity (52.2\%). People who watch television reported more lack of desire or motivation as a limiting factor to engaging in leisure-time physical activity $(20.7 \%)$ - Table 2.

\section{Discussion}

The results of the present study revealed that lack of time, lack of desire or motivation, dislike exercising, health problems and lack of money, respectively, were the barriers most cited to not engaging in leisure-time physical activity in adults from a region with low socioeconomic level in São Paulo city, Southeast, Brazil. The vulnerable groups to lack of time were people married, young and middle aged, and with longer labor journey. Health problems were related by people with hypertension, diabetes, heart diseases, elderly, with low education and who did not have labor activities. People who were not working, with low education and income, and with hypertension related more often dislike of exercising. Lack of desire or motivation was more frequent among people who watched television.

After grouping and categorization the results showed that barriers were similar to the study of Reichert et al. ${ }^{12}$, which was conducted with a representative sample of adults from Pelotas, South of Brazil. This study was one of the first population-based investigating perceived barriers to physical activity and showed that lack of money (40.3\%), feeling too tired (38.1\%), lack of company (32.2\%) and lack of time (31.5\%) were the most frequently reported barriers to engaging in physical activity. The multivariate analysis revealed that lack of time, dislike exercising, feeling too tired, lack of company, and lack of money, in this order of importance, were associated with leisure-time physical inactivity and that the number of perceived barriers was directly proportional to the prevalence of physical inactivity during leisure time.

However, there is a scarcity of studies investigating perceived barriers to engaging in physical activity in Brazil, mainly in people that living in low socioeconomic places, because the barriers can be different according to socioeconomic levels ${ }^{21}$. Sistematic review about Brazilian studies showed that we had eight studies with adults and six studies with elderly ${ }^{13}$. However, never of these studies were conducted with randomized sample that lived in the low socioeconomic region. This study showed also that intrapersonal factors as lake of time and lake of motivation were the main barriers to physical activity in leisure time in adults.

Other original studies has shown that the main barriers reported in the adult population are lack of time, diseases and motivational issues ${ }^{21-23}$. The study of Fox et al. ${ }^{10}$ in 291 adults from East Harlem in New York, USA, found that the three most commonly reported barriers were being too tired, pain with exertion, and lack of time. These barriers are similar to the top three out of the five barriers identified in the present study, namely, lack of time, lack of desire or motivation, and have an injury or disease, demonstrating that personal barriers prevailed in the population studied. Also in Brazil, Nogueira \& Sousa ${ }^{23}$ showed that the lack time was the main barrier to leisure-time physical activity in adults from Santa Maria, South ${ }^{23}$.

However, systematic review about Brazilian studies that investigated barriers to physical activity showed 
Table 2 - Prevalence of the five most reported barriers to engaging in leisure-time physical activity and associated factors accordintg to demographic and social characteristics, self-reported of diseases, obesity, television watching, and time spend in transportation to work and to school in adults. Ermelino Matarazzo, Sao Paulo city, São Paulo, Southeast, Brazil. 2007.

\begin{tabular}{|c|c|c|c|c|c|c|c|c|c|c|c|c|c|c|c|}
\hline \multirow{2}{*}{ Variables } & \multicolumn{3}{|c|}{ Lack of time } & \multicolumn{3}{|c|}{$\begin{array}{l}\text { Lack of desire or } \\
\text { motivation }\end{array}$} & \multicolumn{3}{|c|}{ Dislike exercising } & \multicolumn{3}{|c|}{ Health Problems } & \multicolumn{3}{|c|}{ Lack of Money } \\
\hline & $\%^{*}$ & $95 \% \mathrm{CI}$ & $\mathrm{p}_{\text {value }}$ & $\%$ & $95 \% \mathrm{CI}$ & $\mathrm{p}_{\text {value }}$ & $\%$ & $95 \% \mathrm{CI}$ & $\mathrm{p}_{\text {value }}$ & $\%^{*}$ & $95 \% \mathrm{CI}$ & $p_{\text {value }}$ & $\%$ & $95 \% \mathrm{CI}$ & $p_{\text {value }}$ \\
\hline Overall & 39.7 & $33.8-45.9$ & & 18,4 & $14.9-22.4$ & & 6.3 & $4.3-9.1$ & & 5.6 & $3.9-8.0$ & & 3.6 & $2.2-5.8$ & \\
\hline \multicolumn{16}{|l|}{ Gender } \\
\hline Male & 34.7 & $26.5-34.9$ & $0.038^{\mathrm{a}}$ & 16.6 & $11.6-23.3$ & 0.368 & 4.8 & $2.5-9.1$ & 0.217 & 4.6 & $2.7-8.0$ & 0.301 & 3.1 & $1.4-6.8$ & 0.576 \\
\hline Female & 43.7 & $37.5-50.1$ & & 19.8 & $15.5-24.9$ & & 7.5 & $5.0-11.1$ & & 6.5 & $4.4-9.4$ & & 3.9 & $2.2-7.0$ & \\
\hline \multicolumn{16}{|l|}{ Age (years) } \\
\hline $18-39$ & 41.8 & $33.9-50.3$ & $0.002^{\mathrm{a}}$ & 16.6 & $12.1-22.4$ & 0.222 & 5.4 & $3.0-9.3$ & 0.494 & 0.8 & $0.3-2.4$ & $0.001^{\mathrm{a}}$ & 3.2 & $1.7-6.1$ & 0.221 \\
\hline $40-59$ & 42.9 & $34.8-51.3$ & & 21.7 & $14.4-31.5$ & & 7.2 & $3.7-13.9$ & & 8.3 & $5.1-13.2$ & & 4.8 & $2.3-9.5$ & \\
\hline$\geq 60$ & 21.6 & $17.3-26.8$ & & 16.2 & $12.5-20.6$ & & 7.6 & $5.1-11.2$ & & 18.1 & $13.3-24.3$ & & 1.6 & $0.8-3.2$ & \\
\hline \multicolumn{16}{|c|}{ Education (years of study) } \\
\hline $0-3$ & 44.9 & $36.1-54.1$ & 0.244 & 16.6 & $10.1-26.2$ & 0.364 & 13.5 & $8.2-21.4$ & $0.001^{a}$ & 14.7 & $9.7-21.6$ & $0.001^{\mathrm{a}}$ & 5.1 & $2.0-12.8$ & 0.595 \\
\hline $4-7$ & 43.0 & $34.2-52.3$ & & 15.1 & $10.2-21.8$ & & 8.4 & $4.4-15.2$ & & 5.8 & $2.8-11.7$ & & 3.7 & $1.9-7.2$ & \\
\hline$\geq 8$ & 36.8 & $29.6-44.7$ & & 20.1 & $15.4-25.8$ & & 3.6 & $1.8-7.0$ & & 3.2 & $1.8-5.6$ & & 3.1 & $1.6-5.8$ & \\
\hline \multicolumn{16}{|l|}{ Marital status } \\
\hline Married & 48.9 & $41.8-56.1$ & $0.001^{a}$ & 18.3 & $13.1-25.0$ & 0.879 & 6.5 & $3.9-10.4$ & 0.526 & 6.5 & $3.9-10.7$ & $0.001^{\mathrm{a}}$ & 3.6 & $2.1-6.3$ & 0.991 \\
\hline $\begin{array}{l}\text { Separated, widowed, } \\
\text { divorced }\end{array}$ & 27.8 & $19.8-37.4$ & & 20.3 & $12.3-31.5$ & & 8.7 & $4.8-15.1$ & & 10.8 & $7.3-15.9$ & & 3.3 & $1.2-9.1$ & \\
\hline Single & 27.4 & $19.9-36.4$ & & 17.7 & $12.0-25.4$ & & 5.1 & $2.1-11.6$ & & 1.9 & $0.9-3.8$ & & 3.6 & $1.5-8.0$ & \\
\hline \multicolumn{16}{|c|}{ Family Income (minimum wage) } \\
\hline$\leq 3$ & 39.4 & $32.4-46.9$ & 0.370 & 15.4 & $11.0-21.1$ & 0.421 & 9.3 & $6.0-14.2$ & $0.009^{a}$ & 7.8 & $5.0-11.9$ & 0.237 & 5.1 & $2.7-9.2$ & 0.210 \\
\hline$>3-5$ & 40.8 & $31.3-51.0$ & & 19.4 & $13.1-27.7$ & & 3.2 & $0.8-11.2$ & & 6.3 & $2.9-13.2$ & & 1.8 & $0.6-5.6$ & \\
\hline$>5-7$ & 51.3 & $36.2-66.1$ & & 22.4 & $14.9-32.2$ & & 2.9 & $0.9-9.6$ & & 3.7 & $1.3-10.2$ & & 4.7 & $1.6-12.8$ & \\
\hline$>7$ & 38.2 & $23.7-55.2$ & & 23.1 & $13.3-37.0$ & & 1.3 & $0.2-7.2$ & & 2.7 & $0.7-10.1$ & & 1.1 & $0.1-8.3$ & \\
\hline \multicolumn{16}{|c|}{ Weekly working time (hours) } \\
\hline Not working & 27.3 & $22.0-33.3$ & $0.001^{\mathrm{a}}$ & 22.0 & $16.3-29.1$ & 0.069 & 10.6 & $7.1-15.7$ & $0.001^{\mathrm{a}}$ & 10.2 & $6.9-14.8$ & 0.001 & 5.2 & $2.8-9.5$ & 0.134 \\
\hline $6-40$ & 38.7 & $27.5-51.3$ & & 21.7 & $13.6-32.7$ & & 2.0 & $0.6-6.3$ & & 2.0 & $0.5-7.1$ & & 2.0 & $0.6-5.9$ & \\
\hline$\geq 41$ & 53.1 & $43.2-62.8$ & & 13.5 & $9.9-18.2$ & & 4.0 & $1.7-9.1$ & & 2.6 & $1.2-5.5$ & & 2.7 & $1.2-6.0$ & \\
\hline \multicolumn{16}{|l|}{ Hypertension } \\
\hline Yes & 36.4 & $26.3-47.8$ & 0.389 & 21.2 & $14.3-30.4$ & 0.327 & 11.8 & $6.9-19.6$ & $0.003^{a}$ & 15.5 & $9.7-23.9$ & $0.001^{\mathrm{a}}$ & 2.4 & $0.8-7.6$ & 0.504 \\
\hline No & 40.5 & $34.1-47.2$ & & 17.6 & $13.6-22.4$ & & 4.7 & $3.0-7.2$ & & 2.7 & $1.6-4.5$ & & 3.6 & $2.2-6.0$ & \\
\hline \multicolumn{16}{|l|}{ Diabetes } \\
\hline Yes & 30.8 & $18.7-46.3$ & 0.234 & 19.8 & $10.5-34.3$ & 0.804 & 12.2 & $4.2-30.8$ & 0.177 & 18.6 & $7.9-37.8$ & $0.001^{\mathrm{a}}$ & 3.4 & $0.7-15.0$ & 0.996 \\
\hline No & 40.1 & $34.0-46.5$ & & 18.4 & $14.9-22.4$ & & 5.8 & $3.8-8.8$ & & 4.9 & $3.3-7.1$ & & 3.4 & $2.0-5.7$ & \\
\hline \multicolumn{16}{|l|}{ Heart diseases } \\
\hline Yes & 42.9 & $29.2-57.8$ & 0.674 & 17.8 & $9.0-32.2$ & 0.924 & 1.5 & $0.4-5.0$ & $0.008^{\mathrm{a}}$ & 17.1 & $9.1-29.7$ & $0.001^{\mathrm{a}}$ & 3.3 & $0.4-20.9$ & 0.926 \\
\hline No & 39.4 & $33.5-45.7$ & & 18.4 & $14.9-22.6$ & & 6.7 & $4.5-9.6$ & & 4.8 & $3.2-7.2$ & & 3.6 & $2.2-5.8$ & \\
\hline \multicolumn{16}{|c|}{ Obesity $\left(\mathrm{BMI} \geq 30 \mathrm{~kg} / \mathrm{m}^{2}\right)$} \\
\hline Yes & 30.7 & $22.8-39.9$ & 0.051 & 25.2 & $15.7-37.8$ & 0.064 & 9.0 & $3.6-20.6$ & 0.122 & 9.1 & $5.1-15.9$ & 0.058 & 6.1 & $2.6-14.0$ & 0.116 \\
\hline No & 41.7 & $34.7-49.1$ & & 16.7 & $13.0-21.2$ & & 4.3 & $2.9-6.3$ & & 4.7 & $3.1-7.1$ & & 2.9 & $1.7-5.0$ & \\
\hline \multicolumn{16}{|c|}{$\begin{array}{l}\text { Time spent in travel } \\
\text { (to work and/or to school) }\end{array}$} \\
\hline 0 & 29.0 & $23.0-35.7$ & $0.001^{\mathrm{a}}$ & 21.5 & $15.9-28.2$ & 0.282 & 9.7 & $6.4-14.4$ & $0.020^{\mathrm{a}}$ & 10.4 & $7.0-15.1$ & $0.001^{\mathrm{a}}$ & 5.1 & $2.8-9.1$ & 0.181 \\
\hline$<1$ hour & 45.5 & $36.4-55.0$ & & 16.7 & $11.7-23.2$ & & 2.8 & $1.3-6.2$ & & 1.9 & $0.8-4.6$ & & 2.1 & $0.8-5.1$ & \\
\hline$\geq 1$ hour & 52.2 & $40.3-63.8$ & & 14.7 & $9.1-22.7$ & & 5.7 & $1.8-16.5$ & & 2.7 & $1.0-7.1$ & & 3.2 & $1.3-7.7$ & \\
\hline \multicolumn{16}{|l|}{ Television watching } \\
\hline Yes & 40.1 & $33.3-47.4$ & 0.694 & 20.7 & $16.6-25.5$ & $0.009^{a}$ & 6.3 & $4.0-9.6$ & 0.933 & 6.2 & $4.2-8.9$ & 0.200 & 3.5 & $2.1-5.9$ & 0.953 \\
\hline No & 38.0 & $32.1-44.3$ & & 9.6 & $5.2-16.9$ & & 6.5 & $2.7-14.6$ & & 3.7 & $1.5-8.7$ & & 3.7 & $1.6-8.4$ & \\
\hline
\end{tabular}

* Percentages in weighted sample; $\mathrm{a}=\mathrm{p}<0.05$ for chi square-test. ${ }^{* *}$ Minimum wage in 2007 was $\mathrm{R} \$ 380.00$, equivalent to US\$214.69. 
that the main barrier was the lack of motivation for adults and for elderly people. The lack of time was the second most cited in adults and the physical limitations was the second most cited in elderly ${ }^{13}$. Therefore, the thematic about barriers to physical activity in leisure time is not consensual and depend of the place where people living and the social conditions of the people.

In addition, the lack of time appears to be related to the little free time individuals have to carry out their routine daily activities, particularly for leisure activities. In the present study, adults who were married and worked over 40 hours per week reported lack of time as the main barrier to not engaging in leisure time physical activity, corroborating the results of the study performed in Pelotas, by Reichert et al. ${ }^{12}$, which also found that individuals with little free time for leisure activities had a greater likelihood of being physically inactive. Another study showed that the long journeys of the work and study were associated with barriers to physical activity in adults from Maringa, South of Bra$\mathrm{zi}^{24}$. A possible explanation put forward by the authors for this is that the high prevalence of lack of time reported was the fact that people tend to have free time at night and do not consider night-time hours as available for physical activity.

In the present study women reported more frequently the lack of time as a barrier, which might be explained by "double shifts" in cases where, besides working all day, women then engage in household tasks, a factor which may exacerbate lack of time as a barrier to engaging in leisure-time physical activity ${ }^{25}$. However, again, these results were different of the systematic review of Brazilian studies that showed that the prevalence of this barrier was higher in men than women ${ }^{13}$. Probably, the lack of time is most important to people living in low socioeconomic places like many neighborhoods in east zone, Sao Paulo city, because the people need work more hours per week (men and women), and spend more time in transportation.

Lack of desire or motivation also emerged as a important barrier in the present study, being the second most reported factor by the population investigated. Other leisure activities may win over the motivation for physical activity, such as watching television or recreational use of computers and videogames, mainly in low socioeconomic regions, places that can be more problems with violence and safety ${ }^{7}$. Unfavorable physical and social environments may also diminish people's motivation, such as lack of activities and structures that attract them and networks of individuals that support and encourage these activities ${ }^{26}$.

The results of this study showed that individuals aged $\geq 60$ years had greater tendency to perceive health problems as a reason preventing or discouraging them from engaging in leisure-time physical activity compared with individuals aged $<60$ years. In a study with 30 Brazilian institutionalized elderly, Gobbi et al. ${ }^{27}$ noted that health-related barriers were the most common, while lack of time was less perceived, mirroring the results of the present study for this age group. The authors of this study held that for elderly, lack of time is less frequently perceived because this group has very few activities to occupy them in their daily routines. The need for rest and lower ability appear to be health-related factors influencing the perception of elderly, given that in this age group individuals tend to feel more tired and have less physical and motor ability to perform certain activities, which may lead to the perception that they lack the health conditions to engage in physical activity.

Silva et al. ${ }^{25}$ studied 2,265 industrial workers in the state of Rio Grande do Sul (South of Brazil) in 2007 and showed that the variable "income" was associated with the barriers "fatigue" and "lack of desire". And this result is important, because a cross-sectional study conducted from 2006 to 2008 with industrial workers from 24 of the 27 federal units in Brazil ${ }^{28}$ showed that the low prevalences of leisure-time physical activity were associated with lowest income. In the present study, the income also appeared to significantly influence the perceived barriers lack of desire or motivation and health problems, where individuals earning over seven minimum wages per month had a greater tendency to perceive lack of desire or motivation as a barrier to participating in leisure-time physical activity, while those earning three minimum wages cited health problems, dislike exercising and lack of money as the main barriers.

The results of a study of 4,897 Canadian seniors showed that possible barriers were not the limiting factor to participation in physical activity, a finding supported by the high prevalence of physically active individuals (90.6\%). By contrast, there was a low prevalence of physically active elderly in the present study $(30.7 \%)^{8}$. However, when barriers were used to predict nonparticipation in physical activity of the inactive individuals (9.4\%), the cited study found that the main barrier among men was "lack of availability of activities 
or location", while for women "lack of time" was more evident ${ }^{29}$, a pattern also observed and discussed in the present study.

Results of a study that was conducted in 2009 to identify barriers to participation in leisure-time physical activity reported by 65 users (both genders) of a primary health clinic in east region of São Paulo city who had low levels of active and had one or more risk factors for cardiovascular disease, showed that the main barrier to engaging in leisure-time physical activity was "lack of time" which, in turn, was strongly associated with health problems. Therefore, although recognizing the need to take care of their health, the subjects reported not having time for self-care or to engage in leisure-time activities ${ }^{30}$. These results mirror the findings of the present study, which revealed that the main barriers among subjects with arterial hypertension, diabetes or heart disease were lack of time and health problems.

Several limitations inherent to this study should be taken into account. The cross-sectional design precludes the determination of causal relationships. Consequently, in the case of barriers to participation in leisure-time physical activities, it is not possible to determine whether these are indeed the cause of nonparticipation in physical activity, where follow-up studies of the group over time would be necessary to confirm this relationship. Another issue involves identifying the problems associated with the barriers found, where although the main barriers to engaging in leisure-time physical activity were identified few inferences can be made on the possible underlying reasons. This study identified the barriers only among people who did not practice leisure-time physical activity and from an open question that was categorized and analysed later. This is different of most of the studies that used validated questionnaire with closed questions ${ }^{10-12}$. However, closed questions may limit the possible choices of people in the moment to report the barriers.

The strenght of this study was the sample and the place where it was conducted. There are few epidemiologic studies about barriers to leisure-time physical activities with people living in places of low socioeconomic levels in Latin American countries as Brazil that had were conducted with the randomized and representative sample. For example, a systematic review about barriers to physical activity in Brazilian population showed that only one study had a randomized and large sample ${ }^{13}$.
We conclude that the five most common barriers to leisure-time physical activity in a representative sample from Ermelino Matarazzo, Sao Paulo city, Southeast of Brazil, were lack of time, lack of desire or motivation, dislike exercising, health problems, and lack of money, respectively. Demographics and social variables as age, gender, education, income, longer working journeys, time of spend in transportation, marital status, and the presence of diseases are important characteristics to be considered in plans to promote leisure-time physical activity in communities that living in regions of low socioeconomic levels.

\section{Conflicts of interest}

The authors declare no conflicts of interest.

\section{Acknowledgements}

Florindo AA, receiving an research fellowship from the Brazilian National Council for Scientific and Technological Development (CNPq) (grant 306635/2016-0).We would like to extend our thanks for the financial support provided by the Sao Paulo Research Foundation (FAPESP) (process no 2006/57810-0) and by the Scientific and Technological Development $(\mathrm{CNPq}$ ) (process $\left.n^{\circ} 402042 / 2005-0\right)$.

\section{Author' contributions}

Cruz MS, participated in the original design, conducted the analysis and interpretation of data, of write and critical review of the text, and of the final version. Garcia LMT, participated in the analysis and interpretation of the data, revised the text and approved the final version. Andrade DR, participated in the critical revision of the text and approved the final version. Florindo AA, participated in the original design, of the write, of the critical revision of the text and approved the final version.

\section{References}

1. Ciolac EG, Guimarães GV. Exercício físico e síndrome metabólica. Rev Bras Med Esporte. 2004;10(4):319-24.

2. World Health Organization. Global action plan on physical activity 2018-2030: more active people for a healthier world. Geneva: World Health Organization, 2018.

3. Stella F, Gobbi S, Corazza DI, Costa JLR. Depressão no idoso: diagnóstico, tratamento e benefícios da atividade física. Motriz. 2002;8(3):91-8.

4. World Health Organization. Global recommendations on physical activity for health. Geneva, 2010.

5. Florindo AA, Hallal PC, Moura ECD, Malta DC. Prática de atividades físicas e fatores associados em adultos, Brasil, 2006. Rev Saude Publica. 2009;43:65-73.

6. Mielke GI, Hallal PC, Malta DC, Lee IM. Time trends of physical activity and television viewing time in Brazil: 20062012. Int J Behav Nutr Phys Act. 2014;11(1):101. 
7. Florindo AA, Salvador EP, Reis RS, Guimarães VV. Percepção do ambiente e prática de atividade física em adultos residentes em região de baixo nível socioeconômico. Rev Saude Publica. 2011;45:302-10.

8. Salvador EP, Florindo AA, Reis RS, Costa EF. Percepção do ambiente e prática de atividade física no lazer entre idosos. Rev Saude Publica. 2009;43:972-80.

9. Sallis JF, Bull F, Guthold R, Heath GW, Inoue S, Kelly P, et al. Progress in physical activity over the Olympic quadrennium. Lancet. 2016;388(10051):1325-36.

10. Fox AM, Mann DM, Ramos MA, Kleinman LC, Horowitz CR. Barriers to physical activity in East Harlem, New York. J Obes. 2012;2012:8.

11. Herazo-Beltrán Y, Pinillos Y, Vidarte J, Crissien E, Suarez D, García R. Predictors of perceived barriers to physical activity in the general adult population: a cross-sectional study. Braz J Phys Ther. 2017;21(1):44-50.

12. Reichert FF, Barros AJ, Domingues MR, Hallal PC. The role of perceived personal barriers to engagement in leisure-time physical activity. Am J Public Health. 2007;97(3):515-9.

13. Rech CR, Camargo EMD, Araujo PABD, Loch MR, Reis RS. Perceived barriers to leisure-time physical activity in the brazilian population Rev Bras Med Esporte. 2018;24(4):303-9.

14. Fundação Seade. Sistema Estadual de Análise de Dados. Portal de Estatísticas do Estado de São Paulo. Informações dos Municípios Paulistas. Brasil: 2018.

15. Observatório Rede Nossa São Paulo. Indicadores separados por região do município de São Paulo. Brasil, 2018.

16. Hallal PC, Gomez LF, Parra DC, Lobelo F, Mosquera J, Florindo AA , et al. Lessons learned after 10 years of IPAQ use in Brazil and Colombia. J Phys Act Health. 2010;7(2 Suppl):S259-64.

17. Matsudo S, Araújo T, Matsudo V, Andrade DR, Andrade E, Oliveira LC, et al. Questinário internacional de atividade física (IPAQ): estudo de validade e reprodutibilidade no Brasil. Rev Bras Ativ Fís Saúde. 2001;6(2):05-18.

18. Garcia LMT, Osti RFI, Ribeiro EHC, Florindo AA. Validação de dois questionários para a avaliação da atividade física em adultos. Rev Bras Ativ Fis Saúde. 2013;18(3):317-31.

19. Bardin L. Análise de conteúdo. Lisboa: Edições. 2004;70.

20. Câmara RH. Content analysis: from theory to practice in social research applied to organizations. Gerais Rev Interinst Psicol. 2011;6(2):179-91.
21. Sousa TF, Santo SFD, José HPM. Barreiras percebidas à prática de atividade física no nordeste do Brasil. Pensar Prát. 2010;13(1):1-15.

22. Cerin E, Leslie E, Sugiyama T, Owen N. Perceived barriers to leisure-time physical activity in adults: an ecological perspective. J Phys Act Health. 2010;7(4):451-59.

23. Nogueira JAD, Sousa AFM. Barreiras percebidas e etapas de mudança de comportamento relacionadas à prática de atividade física em professores de escolas públicas. Rev Bras Ciênc Mov. 2012;20(1):65-70.

24. Rigoni PAG, do Nascimento Junior JRA, de Souza Costa GNF, Vieira LF. Estágios de mudança de comportamento e percepção de barreiras para a prática de atividade física em universitários do curso de Educação Física. Rev Bras Ativ Fís Saúde 2012;17(2):87-92.

25. Silva SGD, Silva MCD, Nahas MV, Viana SL. Fatores associados à inatividade física no lazer e principais barreiras na percepção de trabalhadores da indústria do Sul do Brasil. Cad Saude Publica. 2011;27:249-59.

26. Lee RE, Cubbin C. Striding toward social justice: the ecologic milieu of physical activity. Exerc Sport Sci Rev. 2009;37(1):10-7.

27. Gobbi S, Caritá LP, Hirayama MS, Quadros Junior ACD, Santos RF, Gobbi LTB. Comportamento e barreiras. Psicol Teor Pesqui. 2008;451-8.

28. Silva KS, Del Duca GF, Garcia LM, da Silva JA, Bertuol C, Oliveira ES, et al. Barriers associated with frequency of leisuretime physical activity among Brazilian adults of different income strata. Scand J Med Sci Sports. 2016;26(2):206-13.

29. Smith KL, Carr K, Wiseman A, Calhoun K, McNevin NH, Weir PL. Barriers are not the limiting factor to participation in physical activity in canadian seniors. J Aging Res. 2012;2012:8.

30. Morais E, Lima PF, Santos C. Barreiras para a prática de exercício físico regular em indivíduos com fatores de risco cardiovascular. Saude Colet. 2010;7(45):282-7.

Receibed: $12 / 07 / 2018$ Approved: 16/11/2018

Quote this article as:

Cruz MS, Garcia LMT, Andrade DR, Florindo AA. Barriers to leisure-time physical activity in adults living in a low socioeconomic area of the Brazilian Southeast. Rev Bras Ativ Fís Saúde. 2018;23:e0041. DOI: 10.12820/rbafs. 23e0041 